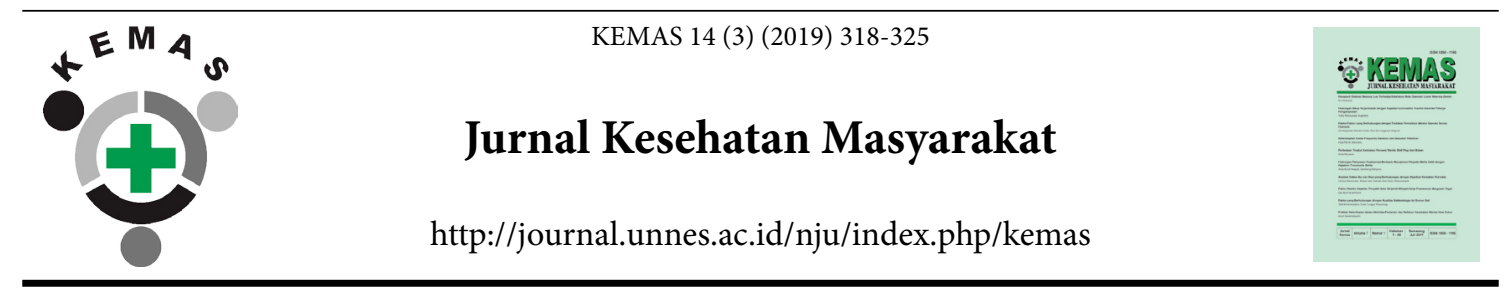

\title{
The Lead Exposure Risk Due to Wells Water Consumption in Code Riverside Community, Yogyakarta City
}

\author{
Musfirah $^{1}$, Ahmad Faizal Rangkuti ${ }^{1}$ \\ ${ }^{1}$ Department of Public Health Science, Universitas Ahmad Dahlan, Indonesia
}

\begin{tabular}{l} 
Article Info \\
\hline Article History: \\
Submitted October 2017 \\
Accepted April 2018 \\
Published March 2019 \\
\hline Keywords: \\
Environmental Health \\
Risk Analysis, Lead, \\
Riverside, Well water \\
\hline DOI \\
https://doi.org/10.15294/ \\
kemas.v14i3.11739
\end{tabular}

\begin{abstract}
The environmental conditions of Code River were strongly influenced by anthropogenic activities that include industry, hospitals, domestic, and agriculture. The contamination status on the Code River according to BLH Yogyakarta reported in 2014 was heavily polluted based on STORET ( $\leq-31)$. The riverside community were misusing the river for final disposal site, potentially contaminating it with lead $(\mathrm{Pb})$. Local communities were potentially exposed to $\mathrm{Pb}$ toxicity through well water consumption. An Environmental Health Risk Assessment (EHRA) study of ingestion exposure of heavy metals was never conducted in the Code Riverside, making it interesting for further studies. The study aimed to determine human health risks of consumption of well water containing $\mathrm{Pb}$ in Code Riverside, Yogyakarta City using an observational design with an Environmental Health Risk Assessment approach. There were 9 environmental samples and 47 respondents selected based on certain criteria. Data was collected through environmental inspection and human health assessment, interviews and anthropometric data measurement of respondents. Data was analyzed by univariate (frequency distribution) and EHRA methods. The result showed that the noncarcinogenic risk level of $\mathrm{Pb}$ due to well water consumption from majority of research sites have RQ value (Risk Quotient) $>1$, which means high potential risk to human health.
\end{abstract}

\section{Introduction}

Heavy metals pollution in water bodies has become a major water quality issue in many fast growing cities over the last few decades (Akoto, 2008). This is because heavy metals pose threats to public water supplies (Terra, 2007) and can also cause health hazard to human consumption of fish and water resources (Akoto, 2014). Today, water pollution is one of the environmental and health issues, especially in areas around rivers.

One of the polluted rivers in Yogyakarta city is the Code River. It has a length of 45.63 $\mathrm{km}$, located in the middle of the city and has a high level of activity related to human and industrial activities (hotels, hospitals, home industries, and agriculture). Most of the surrounding communities around the Code River use this river as a final disposal site, so the water bodies are potentially polluted by heavy metals. Environmental status were based on calculations using the STORET method and associated with the class of river water class and according to each monitoring point, the Code River is classified as seriously polluted. STORET values ranged from -89 to -124 , where this value was far beyond of the minimum limit for severe pollutant category ( $\leq-31)$. The highest 
value (-89) was located at C-3 (Gondolayu Yogyakarta) and the lowest value (-124) was actually upstream at C-1 monitoring point (Boyong Sleman Bridge) (BLH Yogyakarta, 2014). The high polluted status of the river flows as a result of industrial waste in the manufacture of metallic materials, batik craft industry, which utilizes the flow of the Code River as a place of direct waste disposal without any waste treatment first.

The presence of lead in surface water and groundwater depends on the source of the pollutant. $\mathrm{Pb}$ metal as a result of corrosion of mineral rocks due to wave and wind is also one of the source of $\mathrm{Pb}$ that will enter the body of water. $\mathrm{Pb}$ entering water bodies as a result of human activities include waste water (waste) from industries, waste water from mining, lead ore, and waste disposal of the battery industry. In line with previous theory, a study by Ashar (2013) about the concentration of heavy metals in community well water around the pollutant waste disposal (TPA) of 68 wells found only eight wells whose lead concentration exceeds the maximum limit of $0.01 \mathrm{mg} / \mathrm{L}$ according to Permenkes No. 492/Per/IV/2010.

The Code River community is a community that has a risk of being affected by heavy metal pollution in the water. Selected three villages site located along the Code River potentially exposed to lead due to industrial activities, domestic, agriculture, hotels, hospitals are Prawirodirjan, Cokrodiningratan, and Keparakan. The contamination of Code River is suspected to contaminate the residents' wells in the sub-districts around the Code River banks. In accordance with its function, the wells provide water derived from the soil layer relatively close to the surface of the soil. Therefore, it is easily exposed to contamination through the seepage of contaminated river water.Characteristics of metals in an aquatic environment were highly dependent on the speciation of metals. It had affected the presence of these metals in biological tissues (bioavailability) and toxicity to biota, transportation and mobilization (Tahir, 2012) as well as interaction with sediment or soil and will impact ground water and this condition is also related to health impact among community who consumed shellfish and fish contaminated by heavy metal in coastal area (Musfirah, 2016). The heavy metals pollution in river water could contaminate the well water of the community resulting in toxicities in organs such as disorder in renal, neurology, reproduction, and gastrointestinal function. As exposure to chemicals may included foods and beverages, it is necessary to monitor it continuously (Zhou, 2012). Exposure to heavy metals in the soil through drinking water may also harm human health, such as increased blood pressure, headaches, memory and concentration problems and fertility problems (Agusa, 2006). In addition, miscarriages and damage to the nervous system can occur in pregnant women (Ashar, 2013).

Environmental Health Risk Analysis (EHRA) is an assessment or health risks that can occur over time in a risky human population. This predictive study produces quantitative risk characteristics, risk management options and communication strategies to minimize those risks (Bose, 2008). Specific agent-specific environmental quality and site-specific data, anthropometric characteristics and population at risk activity patterns are required for this study (Lain, 2016).

Another heavy metals exposure assessment has been conducted by Mursidi (2015) with Environmental Health Risk Analysis method which shows that the percentage of respondents who have non-cancer risk due to exposure of hexavalent chromium $(\mathrm{RQ} \geq 1)$ is $16 \%$, while the percentage of respondents who has exceeded the limit of non-cancer risk due to arsenic exposure ( $\mathrm{RQ} \geq 1)$ was $59 \%$. The risk of cancer due to the average arsenic exposure in the respondents was 1.5 per 10,000 population.

In line with our study, Naveedullah (2014) showed that anthropogenic and agricultural activities were impacting drinking water quality of the Siling reservoir. Spatiotemporal variations and risk assessment of select heavy metals $(\mathrm{Zn}, \mathrm{Cu}, \mathrm{Mn}, \mathrm{Fe}, \mathrm{Cr}, \mathrm{Cd}$, and $\mathrm{Pb}$ ) were investigated in water samples. During summer, the environmental quality of $\operatorname{Mn}(37.32 \mu \mathrm{g} / \mathrm{L}), \mathrm{Fe}(41.0 \mu \mathrm{g} / \mathrm{L})$, and Cd $(1.18$ $\mu \mathrm{g} / \mathrm{L})$ concentrations were higher in the water samples, while the concentrations of $\mathrm{Zn}(86.12$ $\mu \mathrm{g} / \mathrm{L}), \mathrm{Fe}(42.0 \mu \mathrm{g} / \mathrm{L})$, and $\mathrm{Pb}(30.82 \mu \mathrm{g} / \mathrm{L})$ were dominant in winter. The calculated values for 
chronical daily intake (CDI) were found in the order of $\mathrm{Cr}>\mathrm{Fe}>\mathrm{Mn}>\mathrm{Zn}>\mathrm{Cd}$ in summer and $\mathrm{Zn}>\mathrm{Fe}>\mathrm{Cr}>\mathrm{Pb}>\mathrm{Mn}>\mathrm{Cu}$ during winter. The carcinogenic risk (ECR) via ingestion route for $\mathrm{Cr}, \mathrm{Cd}$, and $\mathrm{Pb}$ were noted to be higher than the acceptable limit $\left(10^{-6}\right)$.

Lead could be toxic to the human body system. In children, lead lowers the level of intelligence, growth, hearing, causes anemia, and can cause attention and behavior disorder. High exposure can result in severe brain damage, even death. Young children are especially susceptible to lead poisoning because they absorb far more lead from their environment than adults and their central nervous system is still in a developing state. The nervous and digestive systems of children are still in the development stage, making them more susceptible to absorbed lead. Children can absorb up to $50 \%$ of lead into the body, while adults only absorb $10-15 \%$. Lead can also poison the red blood cell-production system because it can lead to disruption of red blood cell formation (Widowati, 2008).

The surrounding communities have been using the river for final disposal so that its water bodies are potentially polluted by heavy lead metals $(\mathrm{Pb})$. Locals community are most likely to be exposed to heavy metal toxicity due to the consumption of well water near the banks of the Code River. Whereas generally, we know that exposure to lead is most possible through inhalation paths derived from emissions of motor vehicles. However, other factors are also affected by the lead pollution from the river that permeates to wells because it is located very close to the Code River.

Based on the data of heavy metals in Code River, heavy metal pollution source, and carcinogenic and non-carcinogenic impact in humans, we are interested in measuring the level of lead contained in well water consumed by Cokrodiningratan, Prawirodirjan and Keparakan Community around Riverside Code ,Yogyakarta City. The observational study with the Environmental Health Risks Assessment approach of lead $(\mathrm{Pb})$ combine with water quality assessment, nowadays, has not been applied widely nor properly in that region generally because previous study only reported about water quality assessment and not explain health impact to community by way of ingestion exposures. Therefore, this study aimed to determine the health risks of community due to $\mathrm{Pb}$ metal in well water excavated for drinking water by using specific formula for risk characterization to explain health impact.

\section{Method}

This was an observational study with an Environmental Health Risk Analysis (EHRA) design where risk factors were measured at the same time to predict the magnitude of health risks due to $\mathrm{Pb}$ metal in well water consumed by local community. The study was conducted on August - September 2017 in the Code Riverside of Yogyakarta City. The selected location was based on the consideration that the area is potentially polluted by wastes disposal such as industry, integrated maritime areas, settlements, hotels and agricultural activities. The environmental population were the well water consumed by community in the Code River Bank of Yogyakarta City. The sample of this research were water wells collected from three locations with a total of 9 wells based on certain criteria. Heavy metal content of lead was analyzed using the AAS (Atomic Absorption Spectroscopy) method.

The human population was the entire population living in the Code Riverside. The samples were 47 respondent and sampling method was by purposive sampling. This study used Environmental Health Risk Analysis (EHRA) method with computer program.

\section{Result and Discussion}

The results of this study indicate the risk of $\mathrm{Pb}$ metal due to the consumption of well water in three research sites and was supported by the characteristics of respondents who contribute to health problems. We choose the study site which includes three locations based on the name of the village closest to the riverside Code of Yogyakarta City and being located in the middle of the river across the city of Yogyakarta is Cokrodiningratan, Prawirodirjan, and Keparakan urban village. Respondents in this study amounted to 47 people who consume well water from each urban village. Characteristics of respondents of each urban village is shown below in Table 1.

Table 1 showed that respondents over 
Table 1. Distribution of Respondents Characteristics in the Cokrodiningratan, Prawirodirjan and Keparakan Urban Village around Riverside Code, Yogyakarta City

\begin{tabular}{|c|c|c|c|c|c|c|}
\hline \multirow[b]{2}{*}{ Characteristic } & \multicolumn{2}{|c|}{ Cokrodiningratan } & \multicolumn{2}{|c|}{ Prawirodirjan } & \multicolumn{2}{|l|}{ Keparakan } \\
\hline & $\begin{array}{l}\text { Number } \\
\text { (n) }\end{array}$ & $\begin{array}{l}\text { Percentage } \\
(\%)\end{array}$ & $\begin{array}{l}\text { Number } \\
\text { (n) }\end{array}$ & $\begin{array}{l}\text { Percentage } \\
(\%)\end{array}$ & $\begin{array}{l}\text { Number } \\
\text { (n) }\end{array}$ & $\begin{array}{l}\text { Percentage } \\
(\%)\end{array}$ \\
\hline \multicolumn{7}{|l|}{ Age } \\
\hline$<30$ years old & 1 & 6.7 & 4 & 25 & 4 & 25 \\
\hline $30-40$ years old & 3 & 20 & 2 & 12.5 & 1 & 6.2 \\
\hline$>40$ years old & 11 & 73.3 & 10 & 62.5 & 11 & 68.8 \\
\hline \multicolumn{7}{|l|}{ Educational Level } \\
\hline Not School & 1 & 6.7 & 0 & 0 & 0 & 0 \\
\hline Not graduated elementary school & 2 & 13.3 & 2 & 12.5 & 0 & 0 \\
\hline Elementary school & 5 & 33.3 & 6 & 37.5 & 6 & 37.5 \\
\hline Junior High School & 2 & 13.3 & 1 & 6.2 & 5 & 31.2 \\
\hline Senior High School & 5 & 33.3 & 4 & 25 & 3 & 18.8 \\
\hline College & 0 & 0 & 3 & 18.8 & 2 & 12.5 \\
\hline \multicolumn{7}{|l|}{ Length of stay } \\
\hline$<30$ year & 4 & 26.7 & 5 & 31.2 & 15 & 93.8 \\
\hline 30-40 year & 3 & 20 & 3 & 18.8 & 1 & 6.2 \\
\hline$>40$ year & 8 & 53.3 & 8 & 50 & 0 & 0 \\
\hline
\end{tabular}

Sources : Primary Data 2017

40 years old were the most common in the population ofCokrodiningratanand Keparakan, amounting to 11 respondents $(62.5 \%)$. The majority of respondents (6 respondents or $37.5 \%)$ had elementary education level in Prawirodirjan and Keparakan and length of stay ( $<30$ years) were found mostly in Keparakan i.e. 15 respondents $(93.8 \%)$ from the total of 16 respondents (100\%).

Preliminary survey showed that local residents use well water for daily consumption, either public wells and private wells located close to the banks of the Code River. The lead concentration $(\mathrm{Pb})$ in well water is analyzed in the laboratory. Well water samples are collected directly by the researchers and assisted by the population of the River Code, City of Yogyakarta. This measurement is needed in order to determine the level of risk. The results of the complete measurement for lead concentration $(\mathrm{Pb})$ levels in well water in the Cokrodiningratan, Prawirodirjan and Keparakan Urban Village around Riverside Code, Yogyakarta City is $1.103 \mathrm{mg} / \mathrm{L} ; 1.187$ $\mathrm{mg} / \mathrm{L} ; 1.195 \mathrm{mg} / \mathrm{L}$, respectively. The standard guideline for $\mathrm{Pb}$ assessment in well water (drinking water) stated the Pb levels is $0.01 \mathrm{mg} / \mathrm{L}$ according to Permenkes No.492 in 2010. The highest concentration of $(\mathrm{Pb})$ environmental samples were found in Keparakan. It can be concluded that all well water samples are unsafe to be consumed by the community because it exceeded quality standard requirements of $\mathrm{Pb}$ heavy metal contamination on well water for drinking water. The high level of $\mathrm{Pb}$ metal in the Keparakan Urban village well water is because it is located in the center area of the city that has concentrated pollution caused by various human activities in urban areas. Lead $(\mathrm{Pb})$ can evaporate and react with oxygen in the air. The source of $\mathrm{Pb}$ pollution was derived from automotive emissions, paint, pipes and cables, plastic, ceramics, cosmetics, antiknock fuel known as Tetra Ethyl Lead (TEL), and was also found in rocks, soil and plants (Direktorat Bina Kesehatan Kerja dan Olahraga, 2012).

Based on observations in the field, the river waters located in Cokrodiningratan urban village, precisely in Kampung Gondolayu, is also potentially very polluted by heavy metal $\mathrm{Pb}$ because of its proximity to the Gondolayu Bridge and densely populated settlements with 
Table 2. Intake (I) and Non- Carcinogenic Risk (RQ) Pb level by well water consumption ( $\mathrm{Dt}=30$ years) Cokrodiningratan. Prawirodirjan and Keparakan Community

\begin{tabular}{lclll}
\hline Location & $\begin{array}{c}\text { C mean } \\
(\mathrm{mg} / \mathrm{L})\end{array}$ & Mean & Min & Max \\
\hline Pb Intake (mg/kg/day) & & & & \\
Cokrodiningratan & 1.103 & 0.0077108 & 0.0024838 & 0.0118410 \\
Prawirodirjan & 1.187 & 0.0079501 & 0.0056286 & 0.0127033 \\
Keparakan & 1.195 & 0.0072197 & 0.0037777 & 0.0114876 \\
Noncarcinogenic (RQ) Pb Level & & & \\
Cokrodiningratan & 1.103 & 1.9277 & 0.6209 & 2.9602 \\
Prawirodirjan & 1.187 & 1.9875 & 1.4071 & 3.1758 \\
Keparakan & 1.195 & 1.8049 & 0.9444 & 2.8719 \\
\hline
\end{tabular}

Sources: Primary Data 2017

various loads of household waste and waste, hotel, and RS. Sardjito. If the river water has been polluted, of course, it can affect the quality of the well water in the vicinity along the river and aquatic biota. The results of this study are consistent with the research of Hong-fei (2010) who reported that the mean concentration of $\mathrm{Pb}$ in local drinking water $(0.139 \pm 0.080) \mathrm{mg} / \mathrm{L}$ exceeded WHO standard $(0.01 \mathrm{mg} / \mathrm{L})$. Thus, lead $(\mathrm{Pb})$ can contribute to health risks through oral exposure (drinking water). It is theoretically reinforced that wells as a source of clean water should be supported under construction terms, site conditions for construction (Buka, 2014). The source of ground water that many people use is water wells. Water wells polluted by both domestic and industrial waste cause negative impacts on human health (Widiyanto, 2015).

Other studies also found that the $\mathrm{Pb}$ levels in fish tissue was higher than that of other heavy metals such as Dellta Niger i.e. $\mathrm{Pb}>\mathrm{Cr}>$ $\mathrm{Ni}>\mathrm{Ag}>\mathrm{Cd}$ with a mean level of $5.12 \pm 1.23 \mathrm{mg} /$ $\mathrm{kg}, 2.69 \pm 1.44 \mathrm{mg} / \mathrm{kg}, 1.94 \pm 0.34 \mathrm{mg} / \mathrm{kg}, 1.02$ $\pm 0.34 \mathrm{mg} / \mathrm{kg}$ and $0.38 \pm 0.08 \mathrm{mg} / \mathrm{kg}$ (Moslen, 2017). In addition, $\mathrm{Pb}$ and $\mathrm{Cd}$ have exceeded the FAO/WHO standard. Potential pollutants in the Azuabie River are anthropogenic, domestic, industrial and municipal waste activities. Fish are contaminated by heavy metals during feeding, causing the food chain to be cut off by many dead biota and as a heavy metal hyperacumulator (Moslen, 2016).

Heavy metals enter the human body through several pathways such as food chain, direct ingestion, dermal contact, fume inhalation, and particles through mouth and nose. Although ingestion is considered to be the primary route of exposure to chemical contaminants in drinking water sources, inhalation and dermal absorption are also increasingly taken into account as important exposure pathways. Seasonal succession of different elements can be a key factor in determining seasonal variation of metal concentrations in different water sources and its relationships with environmental factors. Furthermore, seasonal variations play an important role in metal concentration in soil and water dynamics (Naveedullah, 2014).

The local community who live along the Riverside Code of Yogyakarta City still use the well water as a drinking water every day. Intake estimation data and noncarcinogenic risk level (RQ) of riverside Code community can be seen in table 2.

Table 2 showed the estimation of noncarcinogenic the highest risk level at 30 years duration of exposure with a mean $\mathrm{Pb}$ level in well water of $1.187 \mathrm{mg} / \mathrm{L}$ and showed that the average $\mathrm{Pb}$ intake experienced by the Prawirodirjan respondent was 0.0079501 $\mathrm{mg} / \mathrm{kg} /$ day with the highest intake per day at $0.0127033 \mathrm{mg} / \mathrm{kg} / \mathrm{day}$ and the lowest 0.0056286 $\mathrm{mg} / \mathrm{kg} /$ day. With the daily average intake, the population has an average risk level (RQ) of 1,9875 with the highest risk level of 3.1758 and the lowest of 1.4071. Thus, all research sites are at greatest risk of exposure to $\mathrm{Pb}$ heavy metals because the value of RQ $>1$.

The majority of the population of 
the Code River, especially in the urban areas of Cokrodiningratan, Prawirodirjan, and Keparakan consume well water for the fulfillment of daily needs. This is due to the abundance and ease of obtaining the water without paying any cost and the PDAM pipeline is only affordable for people with higher economies and sometimes the PDAM network does not flow smoothly yet the monthly PDAM bill still charge. The majority of the population of the Code River is in lower middle economic class and their daily income is only sufficient for daily food needs.

Our study is in line with other study reported by Setiyono (2014) in which well water contaminated with $\mathrm{Mn}$ metal is utilized due to unawareness of the community and the inability to find alternative sources of clean water. The results of the examination showed that $\mathrm{Mn}$ level exceeds the standard in 29 wells (69\%) while the remaining 13 wells are still below the provisions. There were even 4 wells that are still used by the community even when the Mn content in the water exceeds the stipulated requirements. The public health impact can be projected if the group's community continues to consume clean water with $\mathrm{Mn}$ levels exceeding the prescribed levels. Manganese (Mn) levels in the environment are increasing in line with increased human and industrial activity. Manganese from human activities can enter the water, soil, air and the environment (Widowati, 2008).

Health problems could occur due to the use of well water containing $\mathrm{Pb}$ contaminants. This metal is very dangerous and has no benefit to the body. If these metals enter the body, it will settle in the target organ of the liver and kidneys, so that in a short time it will give an acute effect and in the long term it will cause chronic effects that will endanger the health of the population. The traditional method for evaluating health effects is to directly compare the measured values with permissible limits, but it is not sufficiently reliable to provide detailed hazard levels and identify concerned contaminants $(\mathrm{Wu}, 2010)$. Health risk assessment is an important tool for estimating the potential health impact in aquatic ecosystems caused by various contaminants (Iqbal, 2012). This method has been applied to evaluate the potential adverse health effects by exposure to contaminated water (Naveedullah, 2014). Another study also explained human impact from heavy metal samples, including six trace metals ( $\mathrm{As}, \mathrm{Cr}, \mathrm{Cu}$, $\mathrm{Mn}, \mathrm{Ni}$, and $\mathrm{Zn}$ ), were detected in $>50 \%$ of the samples. Concentrations of As and Ni exceeded the corresponding standards in $20 \%$ and $58 \%$ of the samples, respectively. As a result, arsenic noncarcinogenic risks were higher than the level of concern in 19\% of the population, whereas carcinogenic risks were $>10(-4)$ for $46 \%$, and $>10(-6)$ for $90 \%$ of the population (Kavcar, 2009).

The results of this study are consistent with study reported by Lain (2016) that for noncarcinogenic health risk estimates in the following year, a 5 to 30 year exposure period is established. It is found that at 30 years exposure, the RQ value is 2.346 which means that if exposure lasts up to 30 years, then there will be noncarcinogenic health risks to be avoided. Another study conducted by Hong Fei (2010), reported that the average daily intake dose $(\mathrm{ADD})$ of $\mathrm{Pb}$ via drinking water and rice consumption was partially up to $4.63 \mu \mathrm{g} /$ $(\mathrm{kg} / \mathrm{d})$ and $2.99 \mu \mathrm{g} /(\mathrm{kg} / \mathrm{d})$. Only ADD of adults through drinking water ingestion exceeded $3.5 \mu \mathrm{g} /(\mathrm{kg} / \mathrm{d}) \mathrm{Pb}$ of provision tolerable daily intake (PTDI) by the joint FAO/WHO Expert Committee on Food Additives (JECFA).

Lead exposure $(\mathrm{Pb})$ in the human body can be through the path of ingestion. Adults absorb $5-15 \%$ of all digested $\mathrm{Pb}$. Lead in the body is able to inhibit the activity of enzymes involved in the formation of hemoglobin $(\mathrm{Hb})$ and part of the $\mathrm{Pb}$ will be excreted through urine and feces while other parts will be bound to proteins, accumulates in the kidneys, liver, nails, tissue, hair and fat. The half-life of $\mathrm{Pb}$ in erythrocytes is 35 days, in the liver and kidney tissue it is 40 days, and 30 days in bone (Widowati, 2008). This is confirmed in the post-exposure of diseases caused by exposure to heavy metals by Direktorat Bina Kesehatan Kerja dan Olahraga (2012) that lead in the body is unneeded, some will be released through the urine (75-80\%) and feces (about 15\%) some will accumulate in the liver, kidneys, fat tissue, and hair.

Concentration of lead in human blood has been related to lead contamination in 
drinking water which could impact health (AlOthman, 2013). High levels of lead in blood are associated with delayed puberty in girls because this might suppress the ovary's production of hormones that prepare a young girl's body to ovulate, or release an ovum, for the first time (Schoeters, 2008). With exposure throughout pregnancy, lead $(\mathrm{Pb})$ can be regulated from bone storage of the material in the blood, eventually crossing the placenta and cause fetal death (Barn, 2014). Short-term exposure to high levels of lead can cause brain damage, paralysis (lead palsy), anaemia and gastrointestinal symptoms. Longer-term exposure can cause damage to the kidneys, reproductive and immune systems in addition to effects on the nervous system. The most critical effect of low-level lead exposure is on intellectual development in young children and, like mercury, lead crosses the placental barrier and accumulates in the foetus. Infants and young children are more vulnerable than adults to the toxic effects of lead. Furthermore, they also absorb lead more readily. Even shortterm, low-level exposures of young children to lead is considered to have an effect on neurobehavioural development. Generally, resident children and adults are at high risk of exposure to $\mathrm{Pb}$ in groundwater through ingestion (Asiedu, 2014). Lead contamination in drinking water is considered unsafe category because it is higher than the standard limit and it is necessary to make community aware about the water quality before drinking. Therefore, the government could play a vital role by offering free testing service to ensure good quality water and risk management for drinking as well as preventing public health problems among community (Hasan, 2017).

\section{Conclusion}

The highest average $\mathrm{Pb}$ content in well water was found in Keparakan Village compared to other locations. The risk level of noncarcinogenic (Risk Quotient/RQ) of $\mathrm{Pb}$ metal due to the consumption of well water of the majority of research sites has a value RQ> 1 , meaning that it is very risky for health. Of course, risk management is needed to control it. It is expected that the community, especially the people who live in Cokrodiningratan Urban Village, Prawirodirjan Urban Village, and Keparakan Village. The River bank Code
Community of Yogyakarta always restrict the daily limit consumption of well water or treat water optimally according to the health requirement by reducing the oral intake rate, lowering the lead during washing and processing food, and reducing exposure frequency $(\mathrm{fE})$ and exposure duration $(\mathrm{Dt})$ of lead.

\section{References}

Agusa, T., 2006. Lead Contamination and Its Human Health Effects in India, Vietnam and Cambodia. Biomedical Research on Trace Element, 17(4), pp. 413-416.

Akoto, O., Bruce, N. T., \& Darko, G., 2008. Heavy Metals Pollution Profiles in Streams Serving the Owabi Reservoir. Afr. J. Environ. Sci. and Tech., 2(11), pp. 354-359.

Akoto, O.B., Bismark, E., Darko, G., \& Adei, E., 2014. Concentrations and Health Risk Assessments of Heavy Metals in Fish from the Fosu Lagoon. Int. J. Environ. Res., 8(2), pp. $403-410$

Al-Othman, A.M., Al-Othman, Z.A., El-Desoky, G.E., Aboul-Soud, M.A., Habila, M.A., Giesy, J.P., 2013. Lead in Drinking Water and Human Blood in Riyadh City, Saudi Arabia. Arabian J Geosciences, 6(8), pp. 3103-3109.

Asiedu, L.O., Cobbina, S.J., \& Obiri, S., 2014. Noncancer Human Health Risk Assessment from Exposure to Cadmium, Copper, Lead And Mercury in Surface Water and Ground Water in Konongo-Odumasi Municipality, Ghana. J. Environ. Chem. Ecotoxicol, 5(4), pp. 106112.

Ashar, T., Santi, D.N., \& Naria, E., 2013. Kromium, Timbal dan Merkuri dalam Air Sumur Masyarakat Sekitar Pembuangan Akhir Sampah. Jurnal Kesehatan Masyarakat Nasional, 7(9), pp. 408-414.

Barn, P., Nicol, A.M., Struck, S., Dosanjh, S., Li, R., Kosatsky, T., 2014. Investigating Elevated Copper And Lead Levels In School Drinking Water. Environ Health Review, 56(4), pp. 96102.

Bose-O'Reilly, S., Lettmeier, B., Roider, G., Siebert, U., Drasch, G., 2008. Mercury in Breast Milk - a Health Infants in Gold Mining Areas?. Int. J. Hyg. Environ. Health, 21, pp. 615-623.

BLH., 2014. Laporan Status Lingkungan Hidup DIY Tahun 2014, Yogyakarta.

Buka, I., Hiola, R., \& Amalia, L., 2014. Pengaruh Jarak Antara Sumur Dengan Sungai Terhadap Kualitas Air Sumur Gali Di Desa Talumopatu Kecamatan Mootilango Kabupaten Gorontalo. Artikel Kesehatan 
Masyarakat. Universitas Negeri Gorontalo.

Direktorat Bina Kesehatan Kerja dan Olahraga., 2012. Penyakit Akibat Kerja Karena pajanan Logam Berat. Jakarta: Kementerian Kesehatan Republik Indonesia.

Hasan, M., Begum, L., Hosain, S., Poddar, P., Chowdhury, A., and Ali, F., 2017. Study on Heavy Metals (Zinc and Lead) in Drinking Water of Tannery Area, Adjacent Areas and Outside Village Areas. Journal of Environmental \& Analytical Toxicology, 7(2), pp. 1-3.

Hong-fei, S., Yong-hua, L., Yan-fang, J., Lin-sheng, Y., Wu-yi, W., Hai-rong, L., 2010. Environmental Contamination And Health Hazard Of Lead And Cadmium Around Chatian Mercury Mining Deposit In Western Hunan Province, China. Trans. Nonferrous Met. Soc. China, 20, pp. 308-314.

Iqbal, J., \& Shah, M.H., Health Risk Assessment of Metals in Surface Water from Freshwater Source Lakes, Pakistan. Hum. Ecol. Risk Assess, 19(6), pp. 1530-1543.

Kavcar, P., Sofuoglu, A., Sofuoglu, S.C., 2009. A Health Risk Assessment for Exposure to Trace Metals Via Drinking Water Ingestion Pathway. Int. J. Hyg. Environ. Health, 212(2), pp. 216-227.

Lain, B., Hanadi.Y., Joko, T., 2016. Analisis Risiko Kesehatan Lingkungan Pajanan Merkuri Pada Masyarakat Di Area Penambangan Emas Tanpa Ijin (Peti) Desa Kayeli Kabupaten Buru Provinsi Maluku. Jurnal Kesehatan Masyarakat (e-Journal), 4(2), pp. 129-138.

Moslen, M., \& Miebaka, C.A., 2016. Temporal Variation of Heavy Metal Concentrations in sp obtained from Azuabie Creek in the Upper Bonny Estuary, Nigeria, Current Studies in Comparative Education, Science and technology, 3(2), pp. 136-147.

Mursidi, A., 2015. Analisis Risiko Kandungan Logam Kromium Heksavalen (Cr6+) dan Arsen (As) Dalam Air Minum. Jurnal Vokasi Kesehatan, 1(6), pp. 195-204.

Musfirah, \& Damayanti, S., 2016. Arsenic Exposure to Fish and Shellfish Consumption among
Community in Makassar, Indonesia. International Journal of Public Health Science (IJPHS), 5(4), pp. 437-443.

Naveedullah, H.M.Z., Yu, C., Shen, H., Duan, D., Shen, C., Lou, L., Chen, Y., 2014. Concentrations and Human Health Risk Assessment of Selected Heavy Metals in Surface Water of the Siling Reservoir Watershed in Zhejiang Province, ChinaPol. J. Environ. Stud, 23 (3), pp. 801-811.

Schoeters, G., Den, H.E., Dhooge, W., Van, L.N., Leijs, M., 2008. Endocrine Disruptors and Abnormalities of Pubertal Development. Basic Clin. Pharmacol. Toxicol, 102(2), pp. 168-175.

Setiyono, A., 2014. Studi Kadar Mangan (Mn) Pada Air Sumur Gali Di Desa Karangnunggal Kecamatan Karangnunggal Kabupaten Tasikmalaya. Jurnal Kesehatan Komunitas Indonesia, 10(1), pp. 973-981.

Tahir, A., 2012. Ekotoksikologi Dalam Perspektif Kesehatan Ekosistem Laut. Bandung: Karya Putra Darwati.

Terra, B.F., Araújo, F.G., Calza, C.F., Lopes, R.T., \& Teixeira, T.P., 2007. Heavy Metal in Tissues of Three Fish Species from Different Trophic Levels in a Tropical Brazilian River. Water Air Soil Pollution, 187, pp. 275-284.

Widiyanto, A.F., Yuniarno, S., \& Kuswanto., 2015. Polusi Air Tanah Akibat Limbah Industri dan Limbah Rumah Tangga. Jurnal Kesehatan Masyarakat (KEMAS), 10(2), pp. 246-254.

Widowati, W., Sastiono, A., Rumampuk, R.J., 2008. Efek Toksik Logam: Pencegahan dan Penanggulangan Pencemaran. Yogyakarta: Andi Offset.

Wu, B., Zhang, Y., Zhang, X., Cheng, S., 2010. Health Risk From Exposure Of Organic Pollutants Through Drinking Water Consumption in Nanjing, China. B. Environ. Contam. Tox, 84(1), pp. 46-50.

Zhou, P., 2012. Dietary Exposure to Persistent Organochlorine Pesticides In 2007 Chinese Total Diet Study. Environment International, 42, pp. 152-159. 